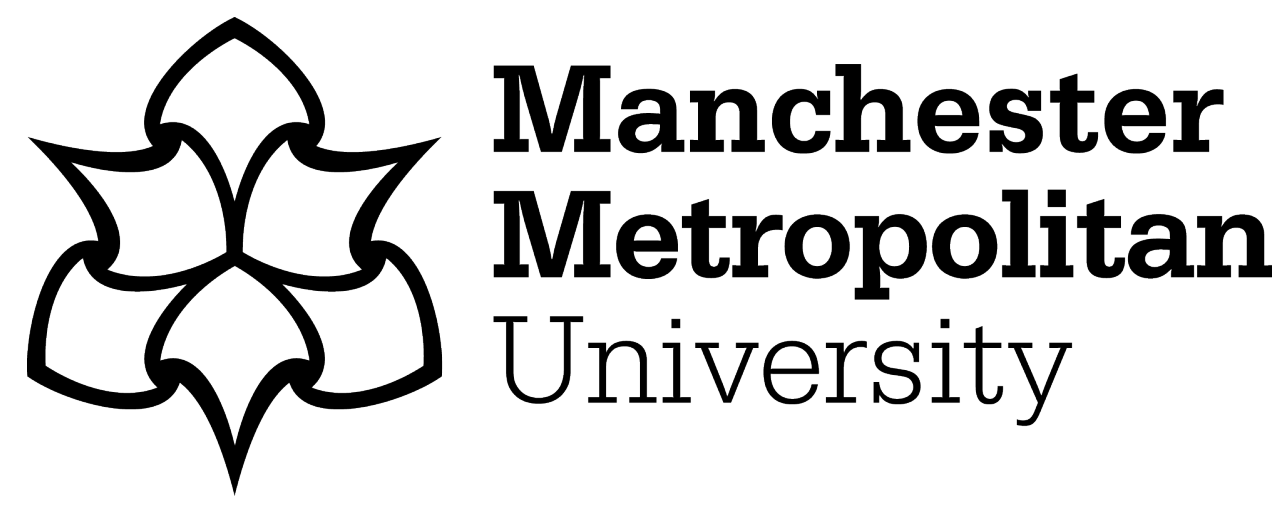

Popan, loan-Cosmin ORCID logoORCID: https://orcid.org/0000-0002-78771652 (2020) Fast and Slow Bicycle Utopias. Utopian Studies, 31 (1). p. 118. ISSN 1045-991X

Downloaded from: https://e-space.mmu.ac.uk/627089/

Version: Accepted Version

Publisher: The Pennsylvania State University Press

DOI: https://doi.org/10.5325/utopianstudies.31.1.0118

Please cite the published version 


\title{
Fast and Slow Bicycle Utopias
}

\author{
Cosmin Popan
}

\begin{abstract}
Faster cycling mobilities are framed as innovations keeping cities on the move while assisting their economic growth. Historically, cycling has nevertheless fostered an ambivalent relation with speed, representing the location of multiple values: modernity, women's emancipation, and working classes' participation but also obsolete technology and "poor man's" transportation. This article problematizes fast cycling and advances a slow utopia as a heuristic framework to reconsider the future. It uses analysis of cultural representations and policy documents to question the underlying assumptions in currently trending visions of cycling. Two policy areas where cycling legitimizes the ideology of economic growth are examined: the mobility policies in London and the British cycling economy. SF literature, graphic novels, and other artistic representations are then used to suggest that slow cycling futures are equally possible. This article is an invitation to outline alternatives to the narratives and practices of speed embedded in late capitalist societies.
\end{abstract}

KEYWORDs: cycling, speed, slowness, economic growth, urban mobilities 


\section{Introduction: Cycling Beyond Utility}

The resurgence of everyday cycling in the last decades across Western cities has engendered lively debates concerning its increasingly relevant role in innovating urban movement toward more sustainable futures. Most cities are building provisions and drafting plans to become more "cycle friendly," and "cycling indexes" are regularly used to rank the best-performing of them, while the World Health Organization has developed a health economic assessment tool to assist evidence-based decision making for cycling investments. ${ }^{\mathrm{T}}$ Meanwhile, the number of cyclists in certain areas of New York has tripled in the past ten years, the number of people cycling to work in London has doubled since 200I, and Paris, the first big city to invest in a bicycle sharing scheme in 2007, aims to increase the number of bike journeys to I5 percent by 2020. ${ }^{2}$ Concurrently, worldwide bicycle production grew sixfold from twenty million units in 1970 to 130 million units by 2007 , and the number of bikes on the planet is growing by more than one hundred million a year. ${ }^{3}$ Ambitious modal share targets, bike hire schemes, and flagship "superhighways" are today established strategies to brand cities as attractive livable environments for tourists, businesses, and skilled professionals. ${ }^{4}$

Cycling has traditionally been framed as the environmentally friendlier and the more socially equitable alternative to car driving. Feminism and socialism in the late nineteenth and early twentieth centuries used cycles as a vehicle to challenge masculine urban spaces and to promote middle-class socialist politics, respectively. ${ }^{5}$ With the 1970s energy crisis, environmentalist and anarchist movements appropriated the bicycle in their struggles for ecological and social justice. ${ }^{6}$ In recent years, nevertheless, the more emancipatory potential of cycling is increasingly challenged by visions placing the bicycle at the forefront of capital accumulation. City cycling policies are designed to boost sustainability, livability, and economic revenues, but at the same time, the structural dominance of automobility remains uncontested.

While historically the bicycle was also intertwined with modernity, industrialism, and capitalism, the contemporary co-opting of cycling in neoliberal discourses and practices is not only a recent development but has also received little academic consideration. ${ }^{8}$ A new field of bicycle economics, or "bikenomics," has started to make headway since the early 2000 s, calculating the benefits of cycling in relation to various indicators: space saving, productive time lost in traffic, health benefits, or job creation. ${ }^{9}$ Yet these quantified 
approaches to cycling promotion offer a narrow perspective, suggesting that cycling is important insofar as it is capable of making a strong economic case. The dominant cycling policy paradigms often exclude any cycling that is not economically productive, being instead concerned "to promote a 'utility' model of transport, prioritising the destruction of distance and the minimisation of time spent travelling." ing cycling with improving labor productivity or enhancing health results in "certain types of cycling [being] promoted as more productive and therefore more important than others." II

This article proposes a critique of seamless and utilitarian cycling underpinning the most recent "cycle boom" in Western cities. It does so by unpacking the notion of speed as a desirable characteristic of urban mobilities and societies and by problematizing aspirations for efficient and effective mobilities. Within this framework, progress and development are only considered possible if speed is not upset. In contrast, the article advances the idea of slow cycling as a means to articulate alternatives to the dominant discourse and to suggest that cycling can open up a different path than that of the current system of automobility.

The fast and slow utopias competing against each other ever since the "invention" of the modern bicycle in the late nineteenth century are concerned with the actual speed of the human-powered machines, but they represent broader social and spatial accelerations as well. They have coincided with the dawn of modernity, reflecting and enabling early industrial capitalist production as well as the more recent unfettered economic growth promoted by neoliberal capitalism. Thus, fast and slow must be understood not merely in terms of velocity measured in kilometers per hour and its affective imprint on the human body but, equally important, in relation to the pace of everyday life.

The remainder of this article is structured as follows. First, it uncovers the links of speed to industrialization, modernity, and capitalist societies, demonstrating how these have impacted on the "naturalization" of speed as intrinsic to contemporary everyday life. Conversely, it is argued that slowness requires more consideration today as practices of speed are strongly linked to unsustainable patterns of energy and resource consumption. The section closes by framing the ensuing discussion on slow and fast cycling from a utopian perspective, which draws on Ruth Levitas's conceptualization of utopias according to their form, function, and content. 
Second, a brief historical perspective, beginning with the "cycle boom" of late 1800 , is presented to highlight the fluctuating relation of cycling with notions of speed, modernity, and progress. The section argues that, historically, cycling has been both fast and slow and demonstrates how the bicycle sped up the Industrial Revolution, pioneered the production line, and revolutionized the advertising industry before paving the way for the faster automobile.

Third, an analysis of contemporary policies pertaining to cycling infrastructure in London is proposed in order to reveal how cycling speed has morphed since the I890s and to describe its intertwinement with the ideology of economic growth. Three policy documents are investigated for this purpose: the Mayor's Transport Strategy and a draft for public consultation, The London Plan. The Spatial Development Strategy for Greater London, as well as a briefing on the economic benefits of walking and cycling, recently published by Transport for London. ${ }^{2}$

Fourth, an exploration of alternative cycling imaginaries is offered by first attending to how cycling lost the battle of innovation with the automobile and was subsequently framed as slow and downward mobility, starting with the 1950s. Consequently, the article brings to the fore the anarchist and environmentalist movements from the I970s to account for how slow cycling became positively valued by the Provo movement in Amsterdam and through the writings of authors such as Ivan Illich. They conceptualized the bicycle not just as an outdated technology but as a convivial one.

Finally, both contemporary and historical science-fiction literature and graphic novels are brought forward to problematize and counterbalance the current discourses and policies on cycling, speed, and sustainable mobilities. Literary and artistic works authored by William Gibson, Ken Avidor, and Mona Caron describe both utopian and dystopian futures where slow cycling is presented as either a hope or warning to guide humanity's survival in "societies beyond oil."'13

\section{Utopias of Fast and Slow Cycling}

Since the dawn of modernity, the concept of speed has been effectively hidden from view. While intimately linked to modernity, social and spatial acceleration is rarely brought into the discussion. Instead, speed has acted as a silent 
background against which modernity, progress, and capitalism unfolded. The sense of living a so-called faster life that contemporary generations experience is an indication of "a genuine and significant shift in temporality that occurs and accelerates specifically in modern societies." ${ }^{24}$

Karl Marx was among the few to unpack the impact of speed upon economies and societies at the dawn of industrialization. In Grundrisse, he highlights the inherently accelerating and globalizing tendencies of capitalism and argues that speed is important to understand changes in how new technologies of production reorder modern space..$^{15}$ Marx describes the significant shift between the use of tools by workers to expand and a mplify cognitive and physical labor and the machine production that the Industrial Revolution made possible. Thus, industrial machinery transforms the relation between the worker and the tools of production: rather than the worker animating the machine, the machine, with its mechanized rhythms and speed superior to that of humans, now animates and alienates the worker. Still, most classic social theorists have not developed systematic accounts of speed and modernity. Instead, they took the increasing speed within societies "as analytically inseparable from the social dynamics-industrial production, capitalism, individualism - and the social contexts - mass society, urbanism, rationalism, secularization-which they saw as constitutive of modernity." 16

Georg Simmel is perhaps the only one of the early social scientists to acknowledge the triumph of speed over the entirety of social life. In his memorable essay "The Metropolis and Mental Life" Simmel describes the city of Berlin at the beginning of the last century, with its "rapid crowding of changing images, the sharp discontinuity in the grasp of a single glance, and the unexpectedness of onrushing impressions." ${ }^{\prime 17}$ This modern metropolis, with its money economy, the universal diffusion of pocket watches, and the intellectual character of its inhabitants, illustrates best the growing impact of speed upon the development of the individual. The metropolitans grow in response a "blasé attitude" toward things and people, which results from "the rapidly changing and closely compressed contrasting stimulations of the nerves." ${ }^{\prime 8}$

In its connection both to movement and to the broader rate of occurrence of events (something that Rosa calls "technological acceleration" and "acceleration of pace of life," respectively), speed is almost never regarded neutrally, as "it offers both pleasures and pains, exhilarations and stresses, 
emancipation and domination." ${ }^{\text {rg }}$ Yet modern societies have not come so far to a total rejection of its intrinsic value.

Speed neatly embodies the utopian desires embedded within capitalist societies of both the past and the present. Throughout this article, utopian speed operates in two different but complementary modalities. First, speed is apparent through the intensification of production and consumption processes enabled by the industrial capitalism emerging in the late nineteenth century. The early bicycle played an essential role in the development of the new technologies of production described by Marx. Second, there is a more explicit velocity, associated with movement itself. While cycles are slow in comparison with cars, their quickness and nimbleness in congested urban environments are increasingly valued today. In this respect, the factual speed of bicycles is recognized as a vital solution not only to keep cities on the move but also to help sustain desired levels of productivity, flow of capital, and economic growth. Having said that, fast cycling is not a negative category per se. Instead, what are criticized are the ways in which the practice is co-opted to sustain a utopia of unfettered economic growth.

\section{Slowness}

There is a common link between consumer capitalism, declining trends in well-being, and the degradation of the environment. ${ }^{20}$ The damaging nature of speed becomes clearer once we consider the high energy needed to sustain it. Technologies of fast mobilities require energy not only for the act of moving but also for their production, as well as for the infrastructures that enable these mobilities. Since the oil crisis of the I97os, the relation between high-speed mobility systems and energy consumption has been strikingly apparent. Ivan Illich, for example, advocated in 1974 for establishing limits to speed as essential for achieving social justice. He argued that "past a certain threshold of energy consumption for the fastest passenger, a world-wide class structure of speed capitalists is created." ${ }^{2 r}$

Advancing an alternative to fast mobilities entails a dramatic reconsideration of energy consumption but also of capitalist production and consumption more generally. ${ }^{22}$ Thus, slow cycling is not only oppositional to the dominant cultures of speed and immediacy; it also suggests that what represents labor and value in contemporary societies may be assessed and "valued" 
differently. A "norm of sufficiency" and self-limitation become necessary in order to avoid economic and ecological catastrophe and are essential to the political autonomy of individuals and communities. ${ }^{23}$ Slow cycling futures can involve such a norm of sufficiency in relation to both resource consumption and the consumption of space through speeds beyond the bodily capacity of individuals. To be slow is to resist the perpetual quest for profit embedded within capitalism, to resist the desire to maximize wealth for the benefit of the few.

\section{Theorizing Utopia}

During the past two hundred years since its inception, the bicycle has conveyed symbols of both future and past, progress and backwardness, fast and slow technology. It has represented desirable and less desirable futures, for both progressive and conservative aspirations in society. Fast cycling and slow cycling have been, at times, people's hope for or fear of the future. Exploring the promises embedded in visions of preferred futures represents the task of utopian studies, an expanding field of inquiry holding the view that "utopia is not escapist nonsense but a significant part of human culture." 24

Utopia has come to be regarded as an imagined perfect society or specific space that does not and even cannot exist. Yet more recent sociological understandings of utopia see it as processual rather than complete, an open discussion rather than a closed one. ${ }^{25}$ Critical utopias, such as Ursula Le Guin's utopian science-fiction novel The Dispossessed, which emerged from the politics of the I960s and I970s, have partly contributed to this turn, which acknowledges the limitations of the utopian tradition, and "reject utopia as blueprint while preserving it as dream." ${ }^{26}$

Levitas tries to solve the tension between desire and hope, between openness and closure, by proposing an understanding of utopia in terms of content, form, and function. ${ }^{27}$ This article will focus primarily on the first two aspects of utopia: content and form. Examining the content of utopia is important because what constitutes an ideal of "the good society" rarely accommodates everyone's preferences: "There is a common assumption that utopia should be a portrayal of the good society. It is however obvious that this will vary, being a matter not just of personal taste, but of the issues which appear to be important to different social groups, either in the same society 
or in different historical circumstances." ${ }^{28}$ There is not a single bicycle utopia to which humanity has subscribed unconditionally. For some and at certain times in history the bicycle conveyed desires of emancipation and progress, while for others, in other times, it simply translated as backwardness or, on the contrary, simplicity and conviviality.

The form of utopia refers to the manifold manifestations of the utopian imagination, which should not be relegated to literary texts alone. Modern constitutions, political programs, intentional communities, and even daydreaming must also be regarded as utopias. Levitas thinks that "depictions of the good society do not necessarily take the form of literary fictions... Broader historical comparisons require more inclusive definitions, to accommodate changes in the way in which aspirations for a better life may be expressed." ${ }^{29}$ As this article will demonstrate, bicycle utopias can be found in the largely peripheral science-fiction literature of the last few decades, which imagines post-car, sometimes postapocalyptic, and consequently pedal-powered futures. But they are also visible in the actual "bike boom" of the late nineteenth century, which nourished equally utopian ideals of modernization and industrialization, or, more recently, in the urban mobility plans associating cycling with visions of development and economic growth.

Thinking about bicycle utopias in this fashion allows us to consider an extensive range of utopian formulations of cycling futures. Distinctive ideological sensibilities associated with cycling become thus more visible, and so does the multitude of expressions, some artistic, others very pragmatic, that project cycling into the future.

\section{The Fast Cycling Utopias of the Late Nineteenth Century}

The remainder of this article is concerned with contrasting the manifold and often conflicting bicycle utopias from the past and from the present. In this section and the next, it is argued that a utopia of fast, growth-oriented cycling has dominated much of the last two centuries since the first proto-bicycle was "invented." The last two sections are, in turn, concerned with offering alternatives to the dominant discourses and practices of fast cycling.

Modernity and automobility drew many of their ideals from the practices, meanings, materialities, and infrastructures assembled around the "safety bicycle." Modernist movements such as futurism and cubism were 
among the first to embrace the promises of speed made by the early bicycle. They saw the bicycle as the triumph of the mechanical over the mental, and for many of these artists "people didn't ride bicycles, bicycles rode people. The bike was a symbol of Man multiplied by machine." ${ }^{30}$

A 19I3 painting by Italian Futurist artist Umberto Boccioni, Dynamism of a Cyclist (Figure I), illustrates the Futurist preoccupation with speed, modern methods of transport, and depiction of the dynamic sensation of movement but also the role of cycling in fueling these imaginaries. The cubist Jean Metzinger focused on the figure of the sportsman in his painting Au Vélodrome (Figure 2), which is the first in Modernist art to represent a specific sporting event and its champion. In France, the very first edition of the magazine $L e$ Vélocipède illustré, from I869, displayed the voluptuous "Lady Progress" riding a proto-bicycle, the "boneshaker." F. T. Marinetti also wrote that the cyclist, one of the first promoters of the "new religion of speed," was bringing about a new, futurist sensibility. ${ }^{31}$

This "speed craze" around the bicycle starting in the late r8oos should hardly come as a surprise. It coincided with the invention of the so-called

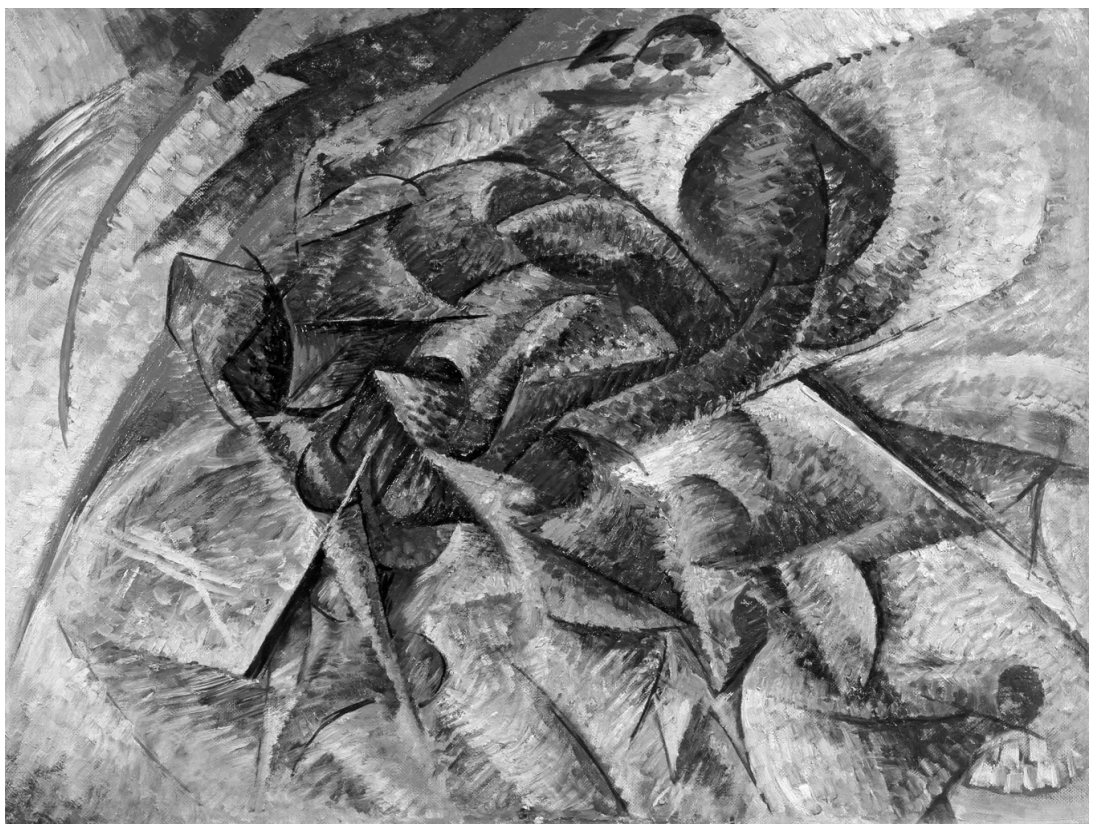

Figure I. Painting by Italian Futurist artist Umberto Boccioni, Dynamism of a Cyclist (Dinamismo di un Ciclista) (1913). 


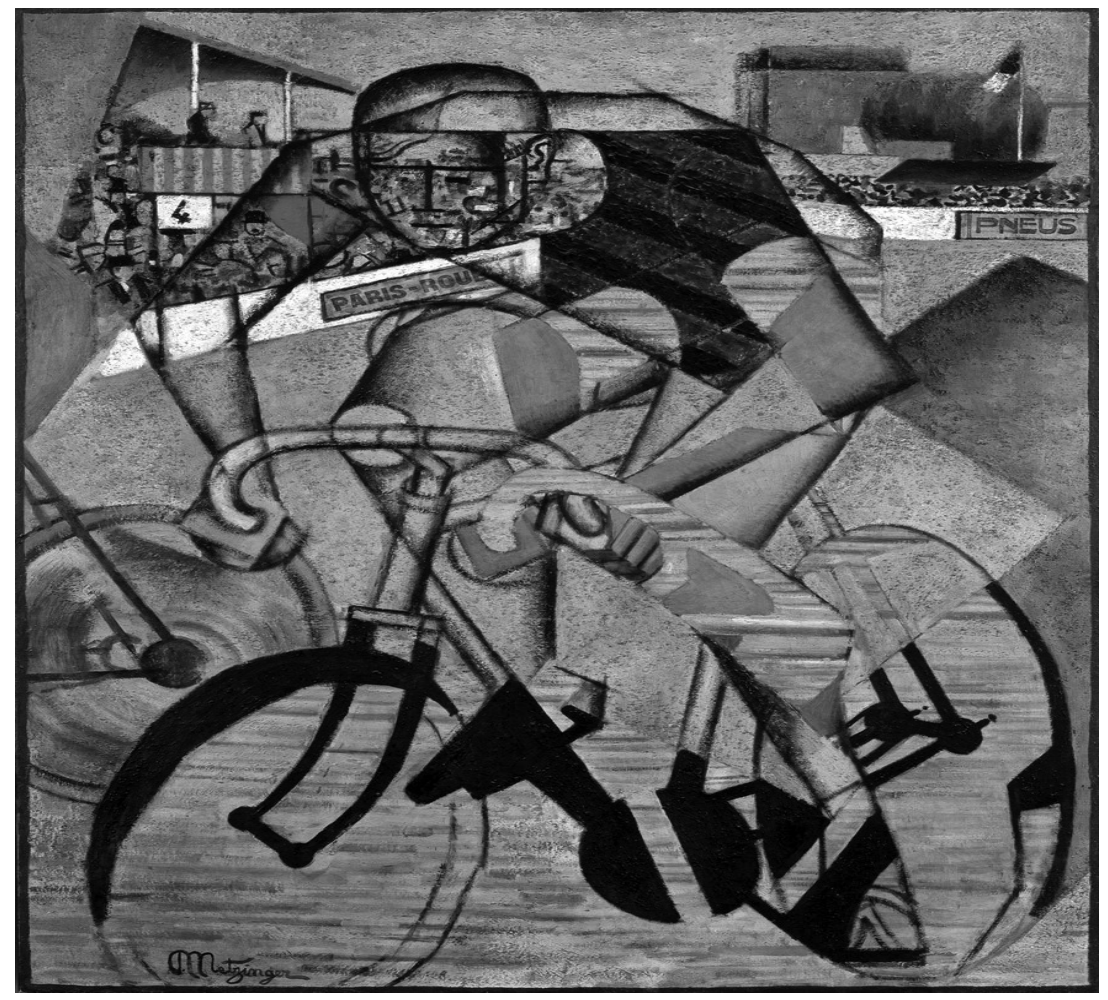

Figure 2. Jean Metzinger's cubist painting Au Vélodrome (19I2).

safety bicycle, featuring equal-sized wheels, a drive chain, and pneumatic tires and thus capable of higher speeds than its predecessor, the high wheeler. The further promotion of its dynamism across the Western world was made possible by a considerable number of very popular cycle races such as the Tour de France or the Tour of Italy, organized for the first time in 1903 and 1909, respectively. Most important was the fact that at the turn of the twentieth century and for quite some time after that, the automobile was still a discrete occurrence in Western cities.

Fast cycling was not only a matter of artistic representation; it was also reflecting broader social and technological changes. The early bicycles and the development of industrial production lines that they made possible testify to the essential role that this technology had in speeding up the early days of capitalist production and consumption. Assembly-line manufacturing and planned obsolescence were related to cycling before they were embraced by automobility. ${ }^{32}$ 
Similarly, the cycling boom set the scene for the modern advertising and marketing industries. Ross Petty shows how promoting the bicycle professionalized the practice of advertising by developing competitive content, using images on posters, and supporting the emergent market of magazines. ${ }^{33}$ Key features of the system of automobility were also put into place during that time, including "the construction of a mobile subjectivity, the development of an entire meaning system around personal transportation, and the disciplining of bodies and the environment in service of autonomous mobility." ${ }^{34}$

The fast cycling utopias of the late nineteenth and early twentieth centuries were short-lived. The bicycle effectively paved the way for the automobile through the early cycling clubs campaigning for better roads in both Europe and North America. ${ }^{35}$ What followed was more than a century of relegating the bicycle to the slow lane of progress, mobility, and capitalist production. The last two decades have nevertheless seen a reversal of this trend, with cycling animating once again fast mobile utopias.

\section{Urban Infrastructure for Fast Cycling and Economic Growth}

There are different $\mathrm{w}$ ays in $\mathrm{w}$ hich $\mathrm{fast} \mathrm{c} \mathrm{ycling} \mathrm{h}$ as a nimated $\mathrm{u}$ topian $\mathrm{d}$ esires throughout the centuries. As the previous section argues, in the late I80os and early 1900 s fast cycling was associated both with the velocity of a mobile technology that preceded the automobile and with the rapid pace of industrialization, to which it contributed decisively. More recently, fast cycling is experiencing a revival. While bicycles have arguably become lighter (thanks to the use of new materials such as aluminum and carbon) and faster (particularly with the e-bike boom), what makes cycling fast is not necessarily its factual velocity but, rather, its assimilation within utopian visions of smart and efficient cities on the move. Increasingly, the bicycle utopias of fast mobilities and economic and technological developments are reinvigorated today in what authors such as Carlton Reid or Jeff Mapes see as a "new bike boom" and a "pedaling revolution." ${ }^{36}$

Cycle superhighways, segregated from car traffic, even suspended above ground level, are perhaps the best illustration of such fast cycling visions. Also, they happen to be the favored representations of many contemporary urban designers and architects (Figure 3). ${ }^{37}$ In these future visions the overwhelming majority of cyclists are represented by young and athletic males, commuting at a fast pace, hardly engaging in any sociable encounters. 


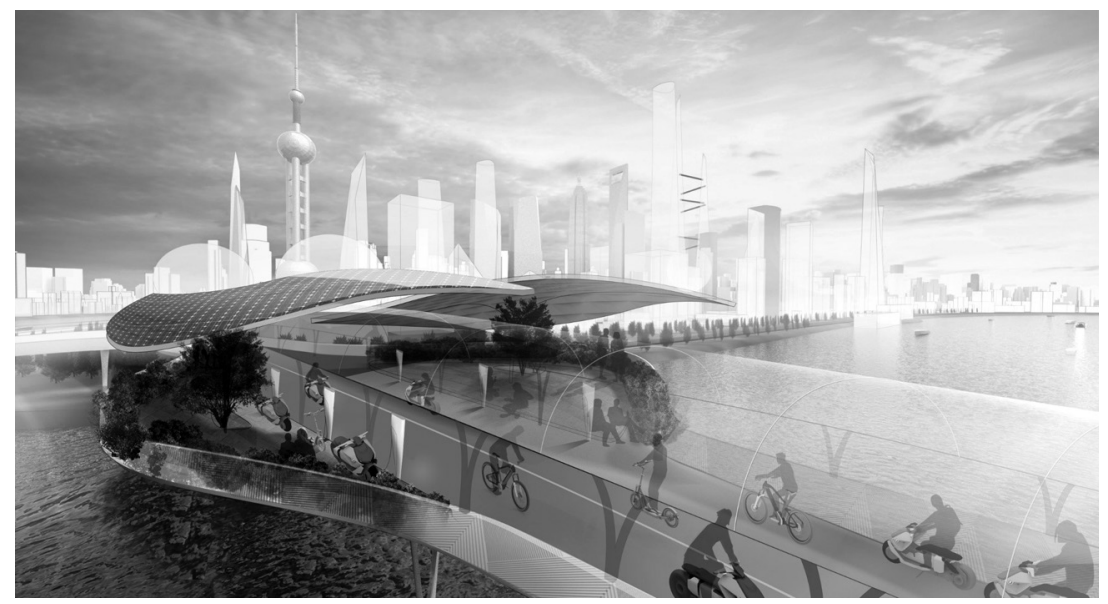

Figure 3. BMW's imagination of cycling futures. Courtesy: BMW Group.

Going beyond such future visions, cycling as fast mobility is intensely advocated and performed through the everyday practices of cyclists, transport engineers, designers, policy makers, and businesses. The European Commission, for example, acknowledges that "a bike is faster than a car over short urban distances ( $5 \mathrm{~km}$ and even more in the case of traffic jams). ${ }^{38}$ Similarly, the city of London clearly states that cycling infrastructure is good for business. According to the Greater London Authority, "Cyclists visit a neighbourhood's shops more often than drivers or public transport users, and spend more overall. Cyclists travel shorter distances to shop than drivers. Cycling can help save precious, but endangered, pubs and small shops." 39 Furthermore, the recently built Cycle Superhighways in London are "expected to enhance the attractiveness of the urban realm for walking and cycling which is likely to strengthen the economic vitality of commercial streets, and is seen as an important means of sustaining London's competitiveness as a place to do business." ${ }^{\circ}$ For their part, businesses also extol the virtues of fast cycling, as data collected by the courier service Deliveroo from millions of smartphone journeys show how cyclists are faster in cities than cars and motorbikes. ${ }^{4}$

Policy documents and briefings issued more recently by London City Hall or by Transport for London further highlight the role of cycling and, more generally, urban mobilities in sustaining first and foremost economic productivity and growth as well as their essential role in attracting business to the city. 
These documents are the Mayor's Transport Strategy, a draft for public consultation titled The London Plan. The Spatial Development Strategy for Greater London, and Transport for London's briefing "Economic Benefits of Walking and Cycling."

In its first few pages, the Mayor's Transport Strategy acknowledges the importance of streets as spaces not only for the seamless movement of vehicles but also for social life: "London's streets should be for active travel and social interaction, but too often they are places for cars, not people." ${ }^{22}$ Yet the document continues by focusing instead on how shifting car mobilities to public transport and cycling mobilities is important principally because they attract businesses: "This simple aim of a shift away from the car ... will revitalise local high streets and attract international businesses and their employees to more pleasant urban centres." ${ }^{43}$

The link between cycling and economic growth is made explicit in the following pages: "In connecting businesses to each other, their employees and their customers, transport has a fundamental role to play in supporting the growth of London's economy." ${ }^{44}$ A similar connection between post-automobility, cycling, and growth is apparent in The London Plan: "The integration of land use and transport, and the provision of a robust and resilient public transport network, are essential in realising and maximising growth and ensuring that different parts of the city are connected in a sustainable and efficient way. In order to help facilitate this, an integrated strategic approach to transport is needed, with an ambitious aim to reduce Londoners' dependency on cars in favour of increased walking, cycling and public transport use. Without this shift away from car use, London cannot continue to grow sustainably." 45

The latest effort to highlight cycling's profit-making capacity and contribution to economic growth belongs to Transport for London, which has recently launched a dedicated online hub for the economic benefits of walking and cycling. The transport authority aims to gather the latest evidence, research, and findings for u se by those "interested in making the economic case for walking and cycling investment." ${ }^{46}$ Part of this effort is a briefing highlighting the economic benefits of more walking and cycling in London, with a focus on areas where they can have a positive impact. Such impacts range from boosting the high street and local town centers to reducing absences and increasing productivity, attracting employees and businesses, and keeping the city moving for business. ${ }^{47}$ For this purpose, the 
document compiles a series of previous reports to show, through a narrow cost-benefit analysis, how cycling provisions translate into investments in the country's economy.

The fact that fast and segregated bicycle lanes, cost-benefit analyses, and quantified health benefits dictate cycling investments today is the result of complex processes. They emerge from the entangled historical aspirations of autonomous mobilities, productive and effective cities and economies, and, at times, discourses about how to make cycling safer and cities more livable. Throughout its early struggles to win the hearts and minds of late nineteenth-century urbanites and its more recent attempts to regain lost ground, cycling has nevertheless too often reflected the dominant ideology. In doing so, it has rarely challenged the orthodoxies of fast mobilities and economic growth. There are, nevertheless, times and places that have witnessed the possibility for different cycling futures and alternative utopias. Cycling can be slow and convivial, accommodating a variety of users and not exclusively concerned with increasing economic outputs. This represents the focus of the next sections.

\section{Slow and Convivial Postwar Utopias}

The content of the bicycle utopia changed dramatically in the decades following World War II, with cycling being systematically rejected from most visions of the future. Progress and prosperity were no longer compatible with cycling. Modernist visions of urban traffic literally and systematically pushed bicycles off the road, and the bicycle began to be represented as slow and backward mobility, relegated to a pastime, childhood, or deviant subjects. ${ }^{48}$ This is visible in TV and cinema productions such as Pee-wee's Big Adventure (1985), In and Out (1997), The 40-Year-Old Virgin (2005), or Premium Rush (20I2), where, as Zack Furness notes, the protagonists are presented "as boyish misfits and/or sexually 'deviant." 49 In the United Kingdom, in particular, the "automobile modernism" leading to the marginalization of cycling was established in the 1960s, with the publication of the influential Buchanan Report, which practically eradicated cycling from the transport landscape. This modernism "left no space for the bicycle and cycling became viewed as deviant, irrational and problematic, with the car installed as the rational 'normal subject."”'50 
The postwar decades, dominated by increasing consumerism and the rise of automobility, witnessed nevertheless the rise of intellectuals and movements that began to appropriate slow cycling as a form of resistance and protest against automobility and capitalism. They were inspired, on the one hand, by student protest movements of the r96os, barricades in Paris, the anti-Vietnam War movement, Situationism, and an anarchist/Marxist subculture and, on the other, by the oil crisis of the ragos and the publication of the famed report The Limits to Growth. ${ }^{\text {.1 }}$

The philosopher Ivan Illich was the first not only to condemn the car and advocate cycling but also to set the bicycle on a different path from that of economic growth, calling it a "convivial tool" capable of effecting autonomy from industrial productivity..$^{52}$ Illich considers the bicycle the only vehicle capable of saving people from the "radical monopoly" of the car, by effecting a dramatic reduction in energy use and time spent working to pay for vehicle ownership. Participatory democracy, he says, "demands low-energy technology, and free people must travel the road to productive social relations at the speed of a bicycle." ${ }^{33}$ His ideal "technological maturity" envisages a world of those who have expanded the extent of their daily horizon "by lifting themselves onto their bicycles." ${ }_{44}$ Going beyond this "tripling" represents for Illich unwarranted speeds and technological excess.

The ideas formulated by Illich and other critical thinkers from the I960s and I970s, such as André Gorz, Jane Jacobs, Guy Debord, and Ernst Friedrich Schumacher, partly inspired the slow bicycle utopian spaces of that time. ${ }^{55}$ The White Bicycle Plan initiated in the mid-1960s in Amsterdam and the ongoing Critical Mass protests are two such legacies. With the advent of the Provo movement in Amsterdam, formed by various anarchists and activists, the bicycle was officially acknowledged as the technological embodiment of environmentalism. The Provos drafted the famous White Bicycle Plan, arguing for the ban of cars from the city center and their replacement with twenty thousand free bicycles provided by the municipality. ${ }^{56}$ The White Bicycle Plan was situated within a broader radical critique of capitalism, the use of public space, and environmental pollution. While the movement reached its climax in the mid-I96os, the Critical Mass protests represent an ongoing slow cycling utopia. 


\section{Contemporary Slow Cycling Utopias and Dystopias}

Cycling in the current capitalist context of Amsterdam (or any other cycling city for that matter) is still slow and convivial compared with other urban environments, but its main purpose remains largely to keep cities on the move and assist their economic growth..$^{57}$ But a more widespread, albeit temporary, slow cycling utopia, which time and again contests the narrow functionalist purpose of road spaces, is that envisaged by the Critical Mass protests.

Today, Critical Mass is the most visible embodiment of a slow biketopia, a "nowtopia," in the words of Carl Carlsson. ${ }^{58}$ Stared in the early I99os in San Francisco, Critical Mass is today a global phenomenon, an international, monthly event where bicyclists briefly take over city streets to celebrate cycling, demonstrate their solidarity, and let the public know: "We are not blocking traffic, we are traffic!" Conceived as "a performative critique of motorized traffic and a critical response to automobility," Critical Mass takes place in more than three hundred cities around the world. ${ }^{59}$ Although the claim of the "massers" is that they are traffic, the group ride itself is anything but fast. The performance aspect of the Critical Mass rides involves a slow pace, which allows constantly riding in a compact group, handing out flyers and informing bystanders about the nature of the event, stopping to take pictures, and so on.

The idea of Critical Mass as both protest and celebration has been further developed by visual artists such as Ugo Gattoni and Mona Caron (https://www.monacaron.com; Figure 4). Gattoni took the concept to the extreme and imagined the mass, unregulated bicycle ride as a permanent feature of urban mobilities in the city of London. Inspired by the 2012 Summer Olympics, Gattoni produced a five-meter-long drawing, Bicycle, featuring bicyclists on the streets of the capital. ${ }^{60}$ His proposition is a big bicycle carnival: "I really wanted to put in bold all the aspects of the cyclists-elite athletes to cycle couriers, commuters, bankers, delivery boys, mums with kids, youths on stolen mountain bikes to fashionistas and hipsters on fixed gear bikes." ${ }^{6 r}$

Yet, in the few instances when bicycles are projected into the future, they are both fast and slow. Indeed, they appear agile in relation to the nonfunctional or no longer existent automobile. But in equal measure they provide slow mobility in postapocalyptic worlds shrunk to a small oasis where bicycles become tools for convivial futures. 


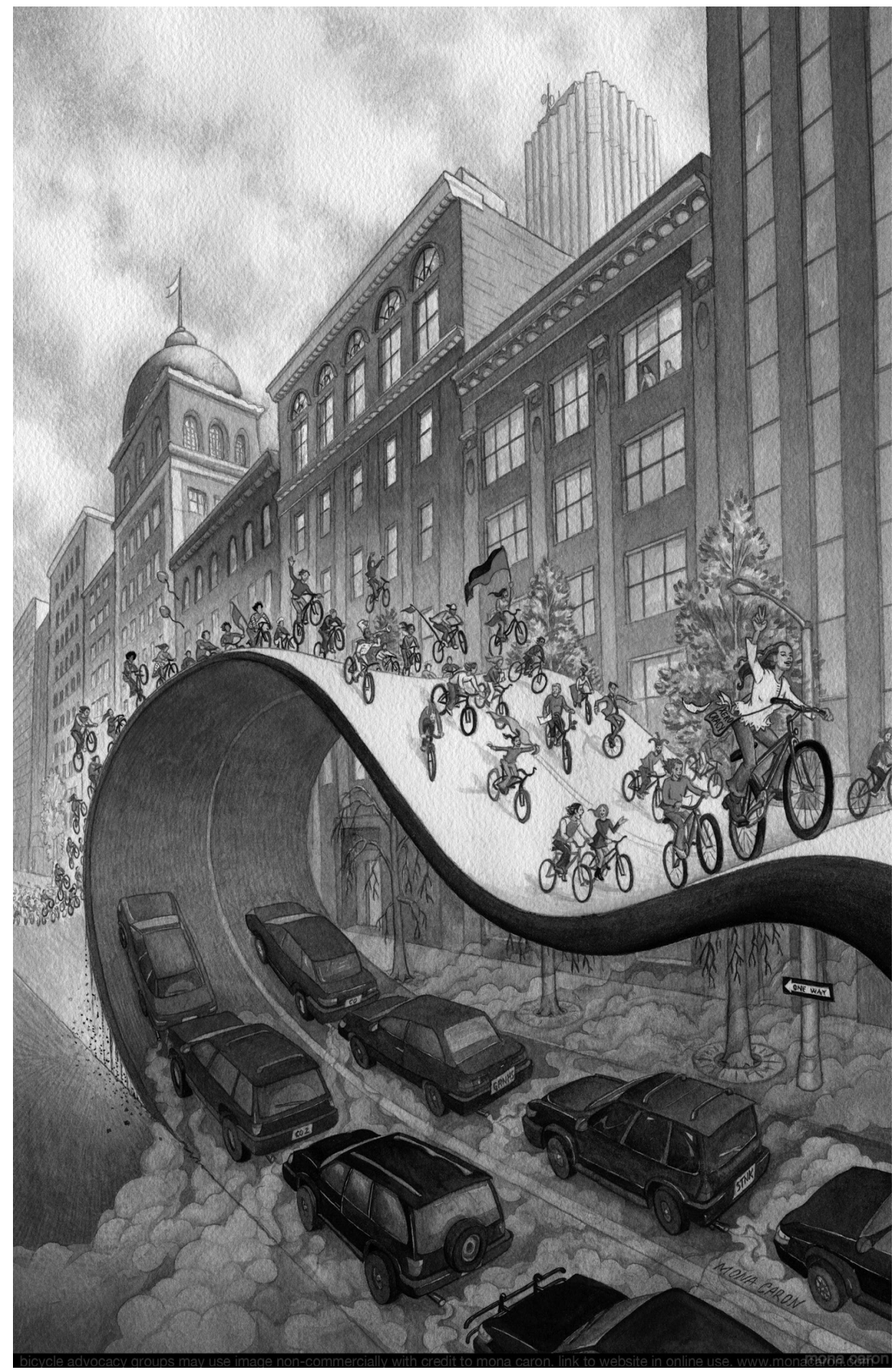

Figure 4. Illustration by Mona Caron (https: / /www.monacaron.com). Courtesy of Mona Caron. 


\section{Cycling Dystopias}

The science-fiction literature of the last three decades has often placed the bicycle as the unlikely means of transportation that people rely on when societies and industries collapse. In a recent web graphic novel, Bicyclopolis (http://bicyclopolis.blogspot.com/; Figure 5), Ken Avidor imagines a postapocalyptic world where the bicycle remains the only option for transportation through a landscape of the rusting wreckage of the industrial age, which is narrated through the eyes of a contemporary time traveler to a biketopia placed sometime after 2050. Bicyclopolis is a remote city in northern America that has survived the massive methane emissions in the Arctic that led to fuel and food shortages and threw the globe into chaos. The city experiments with a postindustrial local economy, based on a "green belt" of kitchen gardens, vineyards, and orchards that surround it. Windmills pump groundwater for irrigation and drinking water for the city, and sheep and goats are grazed in a "pasture belt," whereas a "grain belt" of wheat, soy, and corn is harvested using human-powered machinery. The city has an Ivan Illich Square, and its main industry, bike building, is run by guilds that maintain high standards of production.

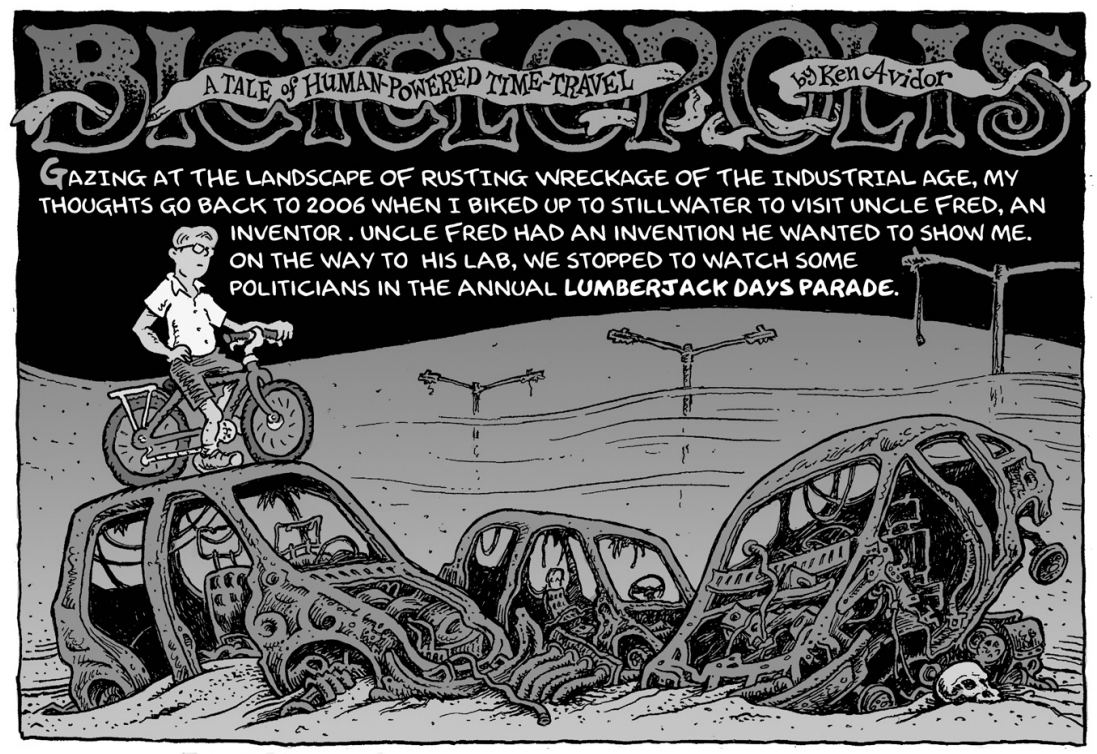

Figure 5. Strip from the Web graphic novel Bicyclopolis by Ken Avidor (2015). Courtesy of Ken Avidor. 
Other short science-fiction stories edited by Elly Blue describe similar scenarios. ${ }^{62}$ The apocalypse presaged here by oil shortages also brings zombies into the script: "In the not-so-distant future, when gasoline is no longer available, humans turn to two-wheeled vehicles to transport goods, seek glory, and defend their remaining communities." ${ }^{33}$ Other authors also show their main characters riding bicycles to move around in post-oil, post-high-energy-density, and often precarious futures. One of the protagonists of William Gibson's Virtual Light is a bike messenger, one of the few jobs left available in a dystopian world where the middle class has disappeared in the face of multinational corporations. ${ }^{64}$ Similarly, Stirling's Dies the Fire describes a future where electricity, gunpowder, and other forms of high-energy-density technology no longer function, leaving humanity with no other option than to turn to bicycles. ${ }^{65}$

In each of these novels and graphic stories, the place of the bicycle lies at the intersection between the promise of a slower, more convivial future and the ominous warning of what a societal collapse looks like. In these accounts, bicycles are both the embodiment of hope for better futures and necessary tools to survive the apocalypse.

\section{Conclusions}

This article argued that throughout history the bicycle has often functioned as a free-floating signifier. The bicycle is indeed "a complex socio-technical object whose meanings and uses are shaped variously through its histories, production, and uses." ${ }^{\prime 66}$ From bourgeois, to working class, to feminist and socialist, to poor man's transportation, to the contemporary "creative class," the bicycle has meant different things to different people at different times in history.

The promises of speed, development, and growth that today drive most of the "cycling renaissance" worldwide are neither new nor benign in their nature. More than a century ago, they similarly set capitalist production and consumption on a fast track, with all the ensuing negative consequences that increased velocities and the annihilation of distances brought upon society and the environment. The utopias of fast cycling not only risk reenacting the "bike boom" moment of the I89os; but they also seem to suggest that no other mobile futures are available. Yet futures can be different, and the utopias of slow, convivial cycling, which have been 
burgeoning alongside the dominant fast narrative, represent just such reasons for hope. The anarchist and environmentalist movements of the last decades might not have defeated automobility or reversed capitalist growth just yet. But through their struggle, they suggest that change is not only desirable-sometimes it is possible.

COSMIN POPAN is a research assistant in the Department of Sociology at Manchester Metropolitan University. He holds a doctorate in sociology from Lancaster University, which has focused on the emergence of a slow bicycle system as a critique of and alternative to growth-oriented economies and societies. His areas of interest are mobilities studies, utopianism, and degrowth. Popan is the author of the book Bicycle Utopias. Imagining Fast and Slow Cycling Futures (Routledge, 2019).

\section{Notes}

I. This work was undertaken within the framework of the Engineering and Physical Sciences Research Council project Liveable Cities (EP/Jor7698/I). Copenhagenize Index, "The Copenhagenize Bicycle-Friendly Cities Index 2017," 20I7, http:/ / copenhagenizeindex.eu/; World Health Organization, "Health Economic Assessment Tool (HEAT) for Cycling and Walking," October 26, 2018, http:/ / www.euro.who.int/en/ health-topics/ environment-and-health/Transport-and-health/activities/guidance-and-tools/ health-economic-assessment-tool-heat-for-cycling-and-walking.

2. Polly Trottenberg, "20I4 NYC In-Season Cycling Indicator. An Estimate of Trends in Regular Cycling for Transportation” (New York: Department of Transportation, 20I5), http:/ / www.nyc.gov/html/dot/downloads/pdf/ 20I4-isci.pdf; Office for National Statistics, "20II Census Analysis, Cycling to Work," March 26, 20I4, http:/ / webarchive. nationalarchives.gov.uk/20160I07092445/http:/ / www.ons.gov.uk/ons/rel/census/ 20II-census-analysis/cycling-to-work/index.html; Mairie de Paris, "Plan vélo," 20I7, https://www.mairier9.paris.fr/ma-mairie/deplacements/plan-velo-208.

3. Harry Oosterhuis, "Aaron Golub, Melody L. Hoffmann, Adonia E. Lugo, and Gerardo F. Sandoval (eds.), Bicycle Justice and Urban Transformation: Biking for All?" Journal of Transport History 39, no. 3 (December I, 2018): 4I2-I4, https: / / doi.org/ IO.II77/ 0022526618759497.

4. Tom Ellerton, "Active Travel: Solutions for Changing Cities," Urban Transport Group, June 2018, http:/ / www.urbantransportgroup.org/system/files/general-docs / UTG\%20\%E2\%80\%93\%20Active \%2otravel\%20solutions\%2ofor\%2ochanging $\% 20$ cities_WEB\%20READY.pdf; Greater London Authority, “The Mayor’s Vision for Cycling in London. An Olympic Legacy for All Londoners," Transport for London, March 20I3, https: / / www.london.gov.uk/sites/default/files / cycling_vision_gla_template_final.pdf; 
European Commission, "Cycling: The Way Ahead for Towns and Cities" (Luxembourg: Office for Official Publications of the European Commission, 1999).

5. Katrina Jungnickel, Bikes and Bloomers. Victorian Women Inventors and Their Extraordinary Cycle Wear (Cambridge: MIT Press, 2018); Zack Furness, One Less Car: Bicycling and the Politics of Automobility (Philadelphia: Temple University Press, 20ro); David Horton, "Social Movements and the Bicycle," Thinking About Cycling (blog), November 25, 2009, http:/ / thinkingaboutcycling.com/social-movements-and-the-bicycle/; Clare Simpson, "Respectable Identities: New Zealand Nineteenth-Century 'New Women'-on Bicycles!' International Journal of the History of Sport I8, no. 2 (June 200r): 54-77, https:// doi.org/10.1080/714001563.

6. Peter Cox, ed., Cycling Cultures (Chester, U.K.: University of Chester Press, 2015); David Horton, "Environmentalism and the Bicycle," Environmental Politics I5, no. I (2006): 4I-58; Provo, "Provo's Fietsenplan," in BAMN (By Any Means Necessary): Outlaw Manifestos and Ephemera, 1965-70, ed. Peter Stansill and David Zane Mairowitz (Harmondsworth, U.K.: Penguin, I97I), 26-27.

7. Oosterhuis, "Aaron Golub, Melody L. Hoffmann, Adonia E. Lugo, and Gerardo F. Sandoval (eds.), Bicycle Justice and Urban Transformation."

8. Furness, One Less Car; Ross D. Petty, "Peddling the Bicycle in the I89os: Mass Marketing Shifts into High Gear," Journal of Macromarketing I5, no. I (1995): 32-46; Justin Spinney, "Fixing Mobility in the Neoliberal City: Cycling Policy and Practice in London as a Mode of Political-Economic and Biopolitical Governance," Annals of the American Association of Geographers 106, no. 2 (2016): 450-58; John Stehlin, "Cycles of Investment: Bicycle Infrastructure, Gentrification, and the Restructuring of the San Francisco Bay Area," Environment and Planning A 47, no. I (2015): I2I-37; Rachel Aldred, "Governing Transport from Welfare State to Hollow State: The Case of Cycling in the UK," Transport Policy 23 (2012): 95-I02.

9. Stefan Gössling and Andy S. Choi, "Transport Transitions in Copenhagen: Comparing the Cost of Cars and Bicycles," Ecological Economics II3 (May I, 2015): I06-13, https:// doi.org/ro.Ior6/j.ecolecon.2015.03.006; Kees van Ommeren and Siebe Visser, "Bikenomics," 20I6, http://www.decisio.nl/wp-content/uploads/Decisio_bikenomics_ workshop_I3102015.pdf; Elly Blue, Bikenomics: How Bicycling Will Save the Economy (Portland, Ore.: Microcosm, 2013); James Jarrett, James Woodcock, Ulla K. Griffiths, Zaid Chalabi, Phil Edwards, Ian Roberts, and Andy Haines, "Effect of Increasing Active Travel in Urban England and Wales on Costs to the National Health Service," Lancet 379, no. 9832 (2012): 2198-2205; Alexander Grous, "The British Cycling Economy: 'Gross Cycling Product' Report," August 20II, http:/ / eprints.lse.ac.uk/38063/.

Io. Rachel Aldred, "A Matter of Utility? Rationalising Cycling, Cycling Rationalities," Mobilities Io, no. 5 (2015): I.

II. Spinney, "Fixing Mobility in the Neoliberal City," 456.

I2. Greater London Authority, Mayor's Transport Strategy, March 20I8, https:// www.london.gov.uk/sites/default/files/mayors-transport-strategy-20r8.pdf; Greater London Authority, The London Plan. The Spatial Development Strategy for Greater London. Draft for Public Consultation, December 2017, https: / /www.london.gov.uk/sites / 
default/files/new_london_plan_december_2017.pdf; Transport for London, "Walking and Cycling: The Economic Benefits" (London, 2018), http:/ / content.tfl.gov.uk/ walking-cycling-economic-benefits-summary-pack.pdf.

I3. John Urry, Societies Beyond Oil: Oil Dregs and Social Futures (London: Zed Books, 2013).

I4. John Tomlinson, The Culture of Speed: The Coming of Immediacy (Los Angeles:

Sage, 2007), I.

15. Karl Marx, Grundrisse: Foundations of the Critique of Political Economy, trans. Martin Nicolaus (New York: Random House, 1973).

I6. Tomlinson, Culture of Speed, 7.

17. Georg Simmel, "The Metropolis and Mental Life," in Simmel on Culture, ed. David Patrick Frisby and Mike Featherstone (London: Sage, 1997), I75.

I8. Ibid., I78.

19. Tomlinson, Culture of Speed, 3; Hartmut Rosa, "Social Acceleration: Ethical and Political Consequences of a Desynchronized High-Speed Society," Constellations Io, no. I (2003): 3-33.

20. Paul Verhaeghe, What About Me? The Struggle for Identity in a Market-Based Society, UK ed. (Melbourne: Scribe UK, 20I4); Naomi Klein, This Changes Everything: Capitalism vs. the Climate (London: Allen Lane, 2014).

2I. Ivan Illich, Energy and Equity (London: Harper and Row, 1974), 29.

22. Kate Raworth, Doughnut Economics: Seven Ways to Think like a Twenty-First-Century Economist (London: Penguin, 2017).

23. André Gorz, Ecologica (Chicago: University of Chicago Press, 2010).

24. Ruth Levitas, The Concept of Utopia (Oxford: Peter Lang, 2010), I-2.

25. Ruth Levitas, Utopia as Method: The Imaginary Reconstitution of Society (Houndmills, U.K.: Palgrave Macmillan, 2013); Levitas, Concept of Utopia; David Harvey, Spaces of Hope (Edinburgh: Edinburgh University Press, 2000); Zygmunt Bauman, Socialism. The Active Utopia (London: George Allen and Unwin, 1976).

26. Tom Moylan, Demand the Impossible: Science Fiction and the Utopian Imagination (London: Methuen, 1986), ro. Ursula K. Le Guin, The Dispossessed: An Ambiguous Utopia (New York: Harper and Row, 1974).

27. Levitas, Concept of Utopia.

28. Ibid., 4-5.

29. Ibid., 5 .

30. Jon Day, Cyclogeography: Journeys of a London Bicycle Courier (Honiton, U.K.: Notting Hill Editions, 20I5), 49.

3I. Filippo Tommaso Marinetti, "The New Religion-Morality of Speed," in Futurism: An Anthology, ed. Lawrence Rainey, Christine Poggi, and Laura Wittman (New Haven: Yale University Press, 2009), 224.

32. Glen Norcliffe, "Popeism and Fordism: Examining the Roots of Mass Production," Regional Studies 3I, no. 3 (1997): 267-80; Furness, One Less Car.

33. Petty, "Peddling the Bicycle in the I89os."

34. Furness, One Less Car, I7. 
35. Carlton Reid, Roads Were Not Built for Cars: How Cyclists Were the First to Push for Good Roads and Became the Pioneers of Motoring (Washington, D.C.: Island Press, 2015); Glen Norcliffe, Ride to Modernity: The Bicycle in Canada, 1869-1900 (Toronto: University of Toronto Press, 200I).

36. Carlton Reid, Bike Boom: The Unexpected Resurgence of Cycling (Washington, D.C.: Island Press, 20I7); Jeff Mapes, Pedaling Revolution: How Cyclists Are Changing American Cities (Corvallis: Oregon State University Press, 2009).

37. BMW Group, "Innovative Urban Mobility Concepts for the Future. Elevated Road Concept 'BMW Vision E3 Way' Raises Emission-Free Two-Wheeler Mobility in Megacities to a New Level," November 22, 20I7, https: / www.press.bmwgroup.com/ global/article/detail/To276388EN/innovative-urban-mobility-concepts-for-the-futureelevated-road-concept-bmw-vision-e3-way-raises-emission-free-two-wheeler-mobilityin-megacities-to-a-new-level?language $=e n$; Foster + Partners, "2013-London, UK. SkyCycle," 20I3, https://www.fosterandpartners.com/projects/skycycle/.

38. European Commission, "Cycling," Iо.

39. Greater London Authority, "Mayor’s Vision for Cycling in London,” 30.

40. Transport for London, "Proposed Cycle Superhighways Scheme," February 4, 2015, http:/ / content.tfl.gov.uk/board-20150204-part-I-item-o7a-propose-csh-scheme.pdf, 63.

4I. Carlton Reid, "Data from Millions of Smartphone Journeys Proves Cyclists Faster in Cities than Cars and Motorbikes," Forbes, November 7, 2018, https://www.forbes.com/ sites/carltonreid/20I8/ II/ o7 / data-from-millions-of-smartphone-journeys-proves-cyclistsfaster-in-cities-than-cars-and-motorbikes / .

42. Greater London Authority, Mayor's Transport Strategy, I2.

43. Ibid., I9.

44. Ibid., 26.

45. Greater London Authority, London Plan, 402.

46. Transport for London, "Economic Benefits of Walking and Cycling," https:// tfl.gov.uk/corporate/publications-and-reports/ economic-benefits-of-walking-and-cycling.

47. Transport for London, "Walking and Cycling," 3.

48. Rorie Parsons and Geoff Vigar, "'Resistance Was Futile!' Cycling's Discourses of Resistance to UK Automobile Modernism 1950-1970," Planning Perspectives 33, no. 2 (April 3, 2018): I63-83, https:/ / doi.org/I0.I080/ 02665433.2017.I348973; James Longhurst, Bike Battles: A History of Sharing the American Road (Seattle: University of Washington Press, 20I7); Le Corbusier, The City of Tomorrow and Its Planning, trans. Frederick Etchells (London: Architectural Press, 197I); Colin Buchanan, Traffic in Towns. A Study of the Long Term Problems of Traffic in Urban Areas (London: Her Majesty's Stationery Office, I963).

49. Furness, One Less Car, III.

50. Parsons and Vigar, "Resistance Was Futile!," I68.

5I. Paul Smethurst, The Bicycle —Towards a Global History (Houndmills, U.K.: Palgrave Macmillan, 20I5); Dana Meadows and Jorgen Randers, The Limits to Growth (New York: Universe Books, 1976).

52. Ivan Illich, Tools for Conviviality (London: Marion Boyars, 1973).

53. Illich, Energy and Equity, I2. 
54. Ibid., 86.

55. André Gorz, Ecology as Politics (Boston: South End Press, 1975); Jane Jacobs, The Death and Life of Great American Cities (New York: Vintage, 196I); Guy Debord, "Situationist Theses on Traffic," Internationale Situationniste 3 (1959); Ernst Friedrich Schumacher, Small Is Beautiful: A Study of Economics as if People Mattered (London: Blond and Briggs, 1973).

56. Provo, "Provo's Fietsenplan."

57. Cosmin Popan, Bicycle Utopias: Imagining Fast and Slow Cycling Futures (Abingdon, U.K.: Routledge, 2019); Marco te Brömmelstroet, Anna Nikolaeva, Meredith Glaser, Morten Skou Nicolaisen, and Carmen Chan, "Travelling Together Alone and Alone Together: Mobility and Potential Exposure to Diversity," Applied Mobilities 2, no. I (2017): I-I5.

58. Carl Carlsson, Nowtopia: How Pirate Programmers, Outlaw Bicyclists, and Vacant-Lot Gardeners Are Inventing the Future Today (Edinburgh: AK Press, 2008).

59. Furness, One Less Car, 299.

60. Ugo Gattoni, Bicycle (London: Nobrow, 2012).

6I. Ugo Gattoni, quoted in Liv Siddall, "Terrifyingly Detailed Cycling Publication by Bicycle-Fanatic Ugo Gattoni for NoBrow," It's Nice That, July 27, 2012, https: / www. itsnicethat.com/articles/ugo-gattoni, para. 4.

62. Elly Blue, ed., Pedal Zombies: Thirteen Feminist Bicycle Science Fiction Stories (Portland, Ore.: Microcosm, 2015).

63. See https:// microcosmpublishing.com/catalog/books/5739.

64. William Gibson, Virtual Light (New York: Penguin, 20II).

65. S. M. Stirling, Dies the Fire (New York: Roc, 2004).

66. Luis A. Vivanco, Reconsidering the Bicycle: An Anthropological Perspective on a New (Old) Thing (New York: Routledge, 2013), 26. 